dr hab. Agnieszka Merkisz-Guranowska, prof. PP

mgr inz. Hanna Stawecka

Politechnika Poznańska

dr inz. Pawet Daszkiewicz

mgr Dawid Gallas,

dr inz. Maciej Andrzejewski

Instytut Pojazdów Szynowych „,TABOR”

\title{
Modern vehicles for shunting operations
}

The article describes the shunting procedures in accordance with the Instruction in the techniques of shunting operations (R-34), shunting locomotives and work they perform during maneuvers was characterized. Methods of performing maneuvers and speed limits for safeguarding the safety of people, vehicles and cargo were presented. A new and modernized locomotive that are currently used in Poland for shunting operations were evaluated. The article also considers special vehicles that can serve as shunting locomotives replacement. Vehicles of this type allow for cost reduction of up to $50 \%$ on the total locomotive life cycle, in addition they emit less noise and meet more stringent emission standards, ensuring the preservation of a safe work environment for employees. Currently, road-rail vehicles can perform shunting work in particular situations where the use of conventional shunting locomotives is not economically viable or simply impossible.

\section{Nowoczesne pojazdy stosowane w pracach manewrowych}

\begin{abstract}
$W$ artykule opisano procedury manewrowe zgodnie $z$ instrukcja o technice pracy manewrowej (R-34), scharakteryzowano lokomotywy manewrowe oraz prace, jakie wykonuja podczas manewrów. Przedstawiono sposoby wykonywania manewrów oraz dopuszczalne prędkości gwarantujace zachowanie bezpieczeństwa ludzi, pojazdów kolejowych i ladunków. Scharakteryzowano nowa i zmodernizowana lokomotywe, które aktualnie sq użwane $w$ Polsce podczas wykonywania prac manewrowych. $W$ artykule przedstawiono także pojazdy specjalne, które mogq zastapić lokomotywy manewrowe podczas wykonywania przez nie prac. Pojazdy tego typu pozwalaja na redukcję kosztów do $50 \%$ w odniesieniu do catkowitego cyklu życia lokomotywy, ponadto emituja mniej hałasu i spetniaja bardziej rygorystyczne normy emisji spalin, gwarantujac zachowanie bezpiecznego otoczenia pracownikom. Aktualnie pojazdy szynowo-drogowe moga wykonywać w szczególności prace tam, gdzie użycie tradycyjnych lokomotyw jest ekonomicznie nieuzasadnione lub po prostu niemożliwe.
\end{abstract}

\section{WPROWADZENIE}

Wśród przedsięwzięć zmierzających do podwyższenia efektywności transportu kolejowego istotną rolę spełniają działania w zakresie obniżenia kosztów eksploatacji i utrzymania pojazdów manewrowych. Drogą do osiagnięcia tego celu jest modernizacja lokomotyw spalinowych lub zastapienie lokomotyw manewrowych pojazdami bardziej ekonomicznymi, dodatkowo uwzględniając uwarunkowania w zakresie emisji spalin i hałasu. Od dziesięcioleci podstawowym źródłem napędu pojazdów wykorzystywanych w pracach manewrowych, w większości przypadków lokomotyw, są silniki o zapłonie samoczynnym (ZS) o przestarzałych konstrukcjach, charakteryzujące się dużą wartością mocy efektywnej i momentu obrotowego, które

\section{INTRODUCTION}

Among the projects, aimed at increasing the efficiency of rail transport, an important role is held by actions aiming to reduce the shunting vehicles operating and maintenance costs. Methods chosen to achieve this goal include upgrading diesel locomotives or replacing shunting locomotives with more economical vehicles, also taking into account the exhaust and noise emissions. For decades, the primary power source for vehicles used in shunting operations, in most cases for locomotives, were compression ignition (CI) engines of obsolete designs, characterized by high values of effective power and torque, but which often do not meet any emission standards and generate high maintenance costs. Tak- 
często nie spełniają żadnych norm emisji oraz generują wysokie koszty utrzymania. Jeśli weźmie się pod uwage pojazdy przeznaczone do najcięższych zastosowań, ich jednostki napędowe charakteryzują się ponadto dużą wartością objętości skokowej, z czego wynika także duże zużycie paliwa oraz duży wydatek spalin. Z powyższego wynika zatem, że eksploatacja lokomotyw manewrowych może powodować dużą energochłonność i znaczną emisję zanieczyszczeń, stąd należy zwracać szczególną uwagę na kwestie zmniejszania ich negatywnego oddziaływania na środowisko.

\section{PRACA MANEWROWA}

\subsection{Przepisy}

Według przepisów kolejowych, zgodnie z instrukcją o technice pracy manewrowej (R-34), manewry są to wszelkie zamierzone ruchy pojazdów kolejowych oraz związane z nimi czynności wykonywane na torach kolejowych z wyjątkiem wjazdu, wyjazdu i przejazdu pociagu. Przestawianie pociagu na stacji z toru na tor, wprowadzenie go na właściwe miejsce (cofanie, podciaganie) po uprzednim zatrzymaniu się na torze, na który został przyjęty, należy uważać za manewry. Składem manewrowym natomiast są pojazdy kolejowe sprzęgnięte $\mathrm{z}$ pojazdem kolejowym $\mathrm{z}$ napędem wykonującym manewry lub zespół trakcyjny wykonujący manewry. Pojazd kolejowy z napędem może znajdować się za, przed lub między pojazdami kolejowymi. Jeżeli na stacji wykonuje się planowe manewry związane z zestawianiem, rozrządzaniem $i$ przerabianiem składów oraz związaną z tym obsługą bocznic stacyjnych i szlakowych, to stacje takie mają przypisane własne lokomotywy manewrowe.

Lokomotywy manewrowe to takie, które zasadniczo posiadają jedną kabinę, z której może być sterowana jazda w dwóch kierunkach. Pojazdy te mogą być elektryczne lub spalinowe.

Celem prowadzenia pracy manewrowej jest [3]:

1) rozrządzanie wagonów na poszczególne tory,

2) zestawianie składów pociagów,

3) wymiana grup wagonów w pociagach,

4) podstawianie wagonów na punkty ładunkowe oraz ich zabieranie,

5) podstawianie i zabieranie próżnych składów pasażerskich na tory przy peronach i postojowe,

6) przestawianie wagonów z jednego toru na drugi,

7) wybieranie wagonów próżnych o szczególnych parametrach technicznych,

8) podstawianie wagonów do wykonania czynności dodatkowych np. czyszczenia, mycia, odkażania, ważenia, naprawy, itp. oraz zabieranie wagonów po zakończeniu tych czynności,

9) wyłączenie $z$ pociagu wagonów $z$ usterkami zagrażającymi bezpieczeństwu ruchu. ing into account the vehicles designed for the toughest applications, their engines are further characterized by a large displacement volume, which results in higher fuel consumption and more exhaust gases. It follows, therefore, that the operation of shunting locomotives can cause high energy consumption and substantial emissions, hence the need to pay special attention to issues of reducing their negative environmental impact.

\section{SHUNTING WORK}

\subsection{Regulations}

According to railway regulations, based on the Instruction in the techniques of shunting operations (R34) shunting includes all intended movements of railway vehicles and related operations on railway tracks with the exception of the train entry, exit and transit. Adjusting the train position at the station from one track to another, pushing it into the desired position (reversing, pulling) after previously stopping on the track, should be considered as shunting maneuvers. A shunting locomotive set are locomotives that are coupled with the rail vehicle performing the shunting maneuvers or multiple unit performing shunting operations. The shunting vehicle may be behind, before or between other units. If the station carries out planned shunting maneuvers in coupling, decoupling and remodeling of train sets, as well as the use of station and track sidings associated with it, such stations are usually assigned their own shunting locomotives to carry out these operations.

Shunting locomotives generally have one cabin, which can be used for driving in both directions. These vehicles could be with electric drives or combustion engines.

The goals of shunting operations include [3]:

1) moving carts into separate tracks,

2) coupling of cart sets,

3) changing a group of carts in a set,

4) moving carts into position for loading and unloading,

5) bringing and taking back of empty passenger carts onto tracks next to platforms and parking them,

6) moving carts between tracks,

7) picking out selected empty carts with distinct characteristics,

8) moving carts into position for special operations such as: cleaning, washing, decontamination, weighing, repairs, etc. and bringing these cars back onto platforms after they are done,

9) taking carts out of trains sets when they are faulty and would impact the train travel safety. 


\subsection{Sposoby wykonywania manewrów}

Stosowane są następujące sposoby wykonywania manewrów [3]:

1) odstawczy, gdzie odstawianie (przetaczanie) polega na przestawianiu taboru na odpowiedni tor (miejsce) i odczepieniu danej grupy taboru po zatrzymaniu,

2) odrzutowy (pojedynczy lub seryjny), gdzie odrzucanie pojedyncze polega na tym, że lokomotywa manewrowa, pchając odprzęgnięta grupę wagonów, przy pewnej określonej prędkości zatrzymuje się, co powoduje, że odprzęgnięte od niej wagony odrywają się i toczą na odpowiedni tor; odrzucanie seryjne polega natomiast na tym, że po odczepieniu pierwszego odprzegu lokomotywa manewrowa rozpędza skład manewrowy do prędkości zapewniającej dojście odprzęgu do wyznaczonego miejsca. Następnie lokomotywa zatrzymuje się w celu umożliwienia odbiegu odczepionego odprzęu, po czym znowu zwiększa prędkość pozwalając na odczepienie następnego odprzęgu drążkiem,

3) grawitacyjny, który polega na staczaniu wagonów z górki rozrządowej lub torów położonych na spadku.

Po zakończeniu rozrządzania na torach kierunkowych lub w celu połączenia składu wagonów w trakcie zestawiania pociagu może mieć miejsce dopychanie wagonów. Odstawianie (przetaczanie) może być wykonywane pojazdem trakcyjnym, pojazdem drogowym, podciagarka, przesuwnicą wagonową lub innym urządzeniem technicznym przeznaczonym do przemieszczania pojazdów kolejowych.

\subsection{Prędkości manewrowania}

Zgodnie z instrukcją Ir-9/R34/ manewry najczęściej wykonywane są na torach zajętych przez tabor, w związku z czym należy je realizować z prędkością gwarantującą zachowanie bezpieczeństwa ludzi, pojazdów kolejowych i ładunku.

Prędkość jazd manewrowych nie może przekraczać $25 \mathrm{~km} / \mathrm{h}, \mathrm{z}$ wyjątkiem następujących przypadków [3]:

1) $40 \mathrm{~km} / \mathrm{h}$ - przy jeździe pojazdu kolejowego $\mathrm{z}$ napędem luzem lub składu manewrowego, gdy pojazdy są ciagnięte po torze wolnym, o czym prowadzący pojazdy kolejowy został powiadomiony; nie dotyczy to jazdy po rozjazdach,

2) $20 \mathrm{~km} / \mathrm{h}$ - przy jeździe przez przejazdy (przejścia) niestrzeżone,

3) $15 \mathrm{~km} / \mathrm{h}$ - przy jeździe składu manewrowego pojazdami kolejowymi naprzód po torze głównym o spadku ponad 2,5 promila, a gdy pojazd trakcyjny nie mógł być umieszczony od strony spadku, podczas podpychania składu do górki rozrządowej na sygnał na tarczy rozrządowej „Podepchnąć skład do górki”,

\subsection{Shunting methods}

The following shunting methods are used [3]:

1) positioning, where the operation (shunting) involves the moving the cart set onto the desired track (place) and the decoupling of any selected carts from the set after it comes to a stop,

2) loose shunting (singular or set), where singular loose shunting means that the shunting locomotive, when pushing a set of carts, stops after reaching the intended speed, which causes the unconnected carts to drift apart and roll onto the desired track; set loose shunting on the other hand involves speeding up of the shunted set after the decoupling of the first connection up to a speed that ensures the shunted set reaches its destination. Then the locomotive stops to allow the decoupled cart set to move away, after which it speeds up again to allow for the detachment of another shunted cart or set,

3) hump shunting, it involves pushing carts off an inclination or a marshalling hill.

Pushing the carts can take place after completion of shunting on the track, or to connect to the cart set in the process of coupling the train. Placement (shunting) can be performed by a: road vehicle, shunter, shifter, or other technical device designed for the movement of rail vehicles.

\subsection{Shunting speed}

According to the instructions Ir-9/R34/ shunting maneuvers are performed most frequently on the tracks occupied by the rolling stock, and therefore to be accomplished with the speed needed to maintain the safety of people, vehicles and cargo.

Shunting vehicle speed must not exceed $25 \mathrm{~km} / \mathrm{h}$, with the exception of the following cases [3]:

1) $40 \mathrm{~km} / \mathrm{h}$ - when driving a rolling railway vehicle or a train set when the vehicles are pulled on an empty track, of which the driver has been notified; does not apply to driving through crossovers,

2) $20 \mathrm{~km} / \mathrm{h}$ - when moving through unmonitored crossings,

3) $15 \mathrm{~km} / \mathrm{h}$ - when moving a train set forward on a main track at a downward slope of over 2.5 thousandth, and when the shunting vehicle could not be placed on the lower end of the whole set, and when pushing a set towards a marshalling hill when signaled to do so,

4) $10 \mathrm{~km} / \mathrm{h}$ - when performing maneuvers with carts occupied by passengers, with dangerous goods, with the exception of marked labels No. 8 or 15 according to the RID, and tanks marked 
a. $\quad 10 \mathrm{~km} / \mathrm{h}$ - przy wykonywaniu manewrów $\mathrm{z}$ wagonami zajętymi przez podróżnych, $\mathrm{z}$ towarem niebezpiecznym, $\mathrm{z}$ wyjątkiem oznaczonych nalepkami nr 8 lub 15 według RID oraz cystern oznaczonych pasem koloru pomarańczowego, dla których obowiązują prędkości mniejsze, z przekroczoną skrajnią lub wyjątkowo ciężkimi o masie powyżej 60 ton $\mathrm{w}$ jednej sztuce po uprzednim zawiadomieniu maszynisty przez kierownika manewrów. Prędkość ta nie dotyczy wagonów zajętych przez podróżnych, jeżeli przetaczanie odbywa się po zabezpieczonej drodze przebiegu,

b. $5,4 \mathrm{~km} / \mathrm{h}$ - przy dojeżdżaniu odprzęgów staczanych $\mathrm{z}$ górki rozrządowej do stojącego taboru na zautomatyzowanych stacjach rozrządowych,

c. $5 \mathrm{~km} / \mathrm{h}$ - jeżeli regulamin techniczny nie postanawia dalszego zmniejszenia prędkości:

- przy spychaniu wagonów $z$ górki rozrządowej na sygnał na tarczy rozrządowej „Pchać z umiarkowaną prędkością,,

- przy rozprzęganiu wagonów drążkiem (widłami),

- przy przetaczaniu wagonów załadowanych towarem niebezpiecznym oznaczonym nalepką ostrzegawczą nr 8 lub 15 według RID oraz cystern oznaczonych pasem koloru pomarańczowego,

- przy jeździe składu manewrowego pojazdami kolejowymi naprzód poprzedzanego przez pracownika, gdy nie może on zająć miejsca na pierwszym pchanym pojeździe kolejowym,

- przy przetaczaniu pojazdów kolejowych silnikowym pojazdem drogowym,

d. 3,6 km/h - przy dojeżdżaniu odprzęgów staczanych z górki rozrządowej do stojącego taboru,

e. $3 \mathrm{~km} / \mathrm{h}$ :

- na sygnał na tarczy rozrządowej „Pchać powoli",

- przy dojeżdżaniu lokomotywy lub pchanego składu manewrowego do stojącego taboru,

- przy przetaczaniu taboru za pomocą urządzeń mechanicznych.

\section{NOWOCZESNE I ZMODERNIZOWANE LOKOMOTYWY MANEWROWE}

Projekt zmodernizowanej lokomotywy manewrowej powstały przy współpracy z firmą PESA Bydgoszcz S.A., to napędowy pojazd kolejowy typu SM42 czteroosiowa lokomotywa o układzie osi B'o B'o i nacisku 18 ton na oś. Lokomotywa ta jest przeznaczona do średnio-ciężkiej pracy przy przetaczaniu, przede wszystkim na bocznicach o rozstawie szyn a. with an orange strip, for which the speeds are smaller, as well as for carts that exceed gauge or are extremely heavy weighing more than 60 tons, in one set after first notifying the driver by the shunting operations head. Speed does not apply to carts occupied by passengers when the shunting is performed on a secured track,

b. $5,4 \mathrm{~km} / \mathrm{h}$ - for uncoupled carts coming down from a marshalling hill towards a stationary set at automated stations,

c. $5 \mathrm{~km} / \mathrm{h}$ - if the technical instructions do not specify further speed reduction:

- when pushing carts off of a marshalling hill after the signaling permitted operation "at moderate speed",

- when uncoupling carts with the uncoupling rod,

- when shunting carts loaded with dangerous goods, marked with a warning label No. 8 or 15 according to the RID, and tanks marked with an orange strip,

- when driving the shunting train set forwards when an employee could not take the place in the first pushed cart or vehicle,

- when shunting carts using a road-based vehicle with combustion engine,

d. $3,6 \mathrm{~km} / \mathrm{h}$ - when carts sets pushed off a marshalling hill approach a stationary train set,

e. $3 \mathrm{~km} / \mathrm{h}$ :

- when the control signal shows ,push slowly”,

- when approaching a stationary train set with a locomotive or a shunted cart set,

- when shunting carts using mechanical shunting devices.

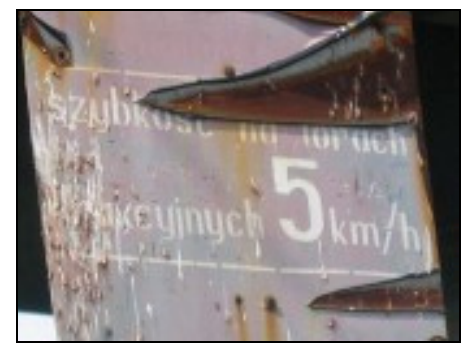

Rys. 1. Tabliczka z informacją o obowiązującej prędkości

Fig. 1. A speed limit label

\section{MODERN AND MODERNIZED SHUNTING LOCOMOTIVES}

The project of a modernized shunting locomotive developed in collaboration with PESA Bydgoszcz $\mathrm{SA}$, is a railway vehicle type SM42 - a four-axle locomotive with the B'o B'o layout and load of 18 tons per axle. This engine is designed for mediumhard shunting work, primarily on sidings with a gauge of $1435 \mathrm{~mm}$ and a speed of $90 \mathrm{~km} / \mathrm{h}$ in the Central European climatic conditions. The locomotive is the 
$1435 \mathrm{~mm}$ i prędkości $90 \mathrm{~km} / \mathrm{h} \mathrm{w}$ środkowoeuropejskich warunkach klimatycznych. Lokomotywa powstała w wyniku kompleksowej modernizacji pierwotnej lokomotywy typu SM42 $[1,4]$.

Lokomotywa manewrowa w wersji $6 \mathrm{Dg}$ jest skonstruowana jako kapotowa $\mathrm{z}$ wieżową kabiną maszynisty, umieszczoną niemalże w środkowej części pojazdu. Podczas modernizacji z pierwotnej lokomotywy spalinowej została wykorzystana rama główna oraz układ jezdny, przy czym w zespołach tych dokonano modyfikacji. W ramie głównej zmiany są uwarunkowane zabudowaniem nowych agregatów. Modyfikacja wózków uzależniona jest od wymagań klienta. Lokomotywa jest rozwiązana jako dwu agregatowa $\mathrm{z}$ parą identycznych agregatów napędowych umieszczonych symetrycznie na obydwu końcach pierwotnej ramy głównej. W części środkowej ramy głównej zabudowana jest nowa kabina typu wieżowego, do której przylegają z jednej strony (z przodu) przedział wyposażenia pneumatycznego a $\mathrm{z}$ drugiej (tylnej) przedział wyposażenia elektrycznego. Agregat napędowy zabudowany jest na samonośnym kontenerze, który jednocześnie tworzy obudowę przedziału. Obydwa kontenery są wzajemnie zamienne i eksploatacyjnie niezależne. Każdy agregat napędowy składa się z silnika spalinowego Caterpillar C15 i alternatora trakcyjnego Siemens. Przenoszenie mocy z silnika spalinowego na zestaw napędowy jest elektryczne, zmienno-stałe (AC/DC). Regulacja mocy oraz całe sterowanie lokomotywą odbywa się przy pomocy elektronicznego systemu regulacyjnego LOKEL.

Lokomotywa ma 3 tryby eksploatacji [4]:

a) ciężkie prace manewrowe - uruchomione są oba agregaty napędowe, przy czym każdy zasila energią elektryczną dwa silniki trakcyjne w sąsiednich wózkach,

b) lekkie prace manewrowe - uruchomiony jeden agregat napędowy, który zasila energią elektryczną wszystkie cztery silniki trakcyjne,

c) awaryjne przetaczanie - jeden uruchomiony agregat napędowy zasila tylko jeden wózek, drugi wózek jest wtedy jedynie toczony. Taka sytuacja może powstać w przypadku awarii silnika trakcyjnego, kiedy dojdzie do celowego odłączenia silników trakcyjnych w jednym wózku lokomotywy.

W lokomotywie zastosowano także równomierne wykorzystanie agregatów napędowych. Oba agregaty napędowe lokomotywy są pełnowartościowe. Podczas eksploatacji można używać tylko jednego lub oba agregaty jednocześnie. Automatyczny system sterowania decyduje o uruchomieniu konkretnego agregatu napędowego w zależności od motogodzin pracy silnika.

Kolejnym nowoczesnym rozwiązaniem są napędowe pojazdy kolejowe typu 741.7 i 742.7 przeznaczone sa do średnio-ciężkiej i ciężkiej pracy przy przetaczaniu result of comprehensive modernization of the original type SM42 locomotive $[1,4]$.

Shunting locomotive version $6 \mathrm{DG}$ is constructed with a tower driver cabin, located almost in the middle of the vehicle. The main frame and chassis were used when upgrading from the original locomotive, but modification has been made in these systems. The main frame changes are caused by the need to provide housing for new aggregates. Modification of the wheelsets depends on customer requirements. The locomotive is designed as two aggregate with a pair of identical propulsion units placed symmetrically on both ends of the original main frame. A new type of tower driver cabin is placed in the central part of the main frame, with the pneumatic equipment compartment adjacent one side (front) and an electrical equipment compartment on the other side (rear). The drive unit is placed on a self-supporting container, which also forms a housing compartment. Both containers are interchangeable and operationally independent. Each drive unit consists of a Caterpillar C15 combustion engine and a Siemens traction alternator. Transferring power from the engine to drive is electric in the form of AC/DC. Power regulation and control of the entire locomotive is done using an electronic regulatory system LOKEL.

The locomotive has 3 modes of operation [4]:

a) heavy shunting - both drive units are running, each feeding electricity to two motors in the neighboring wheelsets,

b) light shunting - one drive unit is running, powering all four wheelsets,

c) emergency shunting - one running drive unit supplies only one wheelset while the other only rolls. Such a situation may arise in the event of engine failure when traction motors in one locomotive wheelset is intentionally disconnected.

The locomotive also uses the even operation of both drive units. Both locomotive drive units are wholesome. During operation, either only one or both units can be used at a time. The automatic control system decides to engage a specific drive unit, depending on the operating hours of the engine.

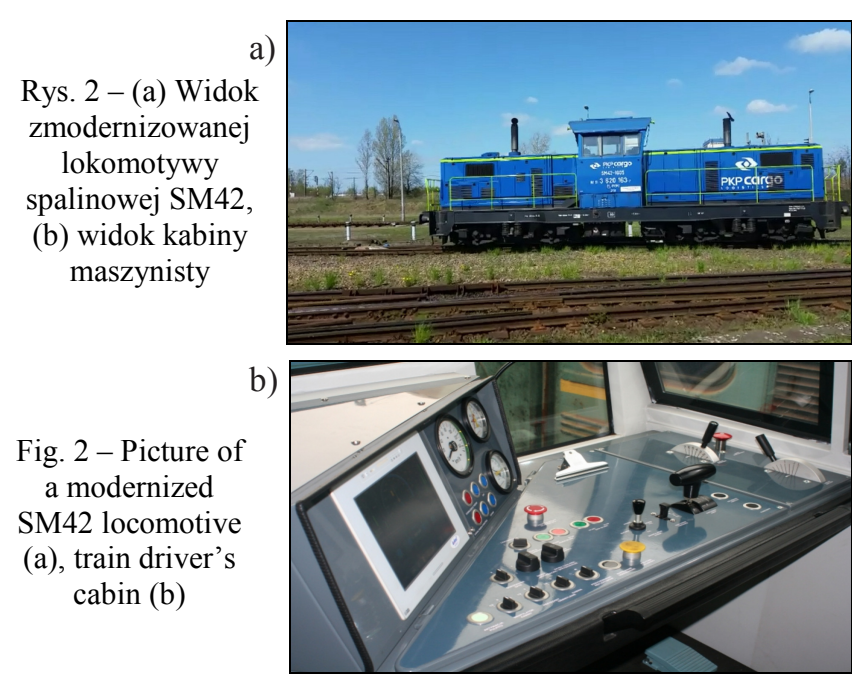


i ruchu na szlakach krajowych, regionalnych i bocznicach o rozstawie szyn $1435 \mathrm{~mm}$. Czteroosiowe lokomotywy o nacisku 18 ton na oś posiadają elektryczne przeniesienie mocy AC/DC. Lokomotywa jest skonstruowana jako rozwiązanie z maską i wieżową kabiną maszynisty, umieszczoną bliżej tylnej czołownicy ramy głównej. Układ osi $\mathrm{w}$ lokomotywie jest typu B'o B'o a maksymalna prędkość jazdy to 100 $\mathrm{km} / \mathrm{h}$. Pojazd powstał w wyniku kompleksowej modernizacji lokomotyw typu 740, 741, 742 (lub pochodnych typów) [6].

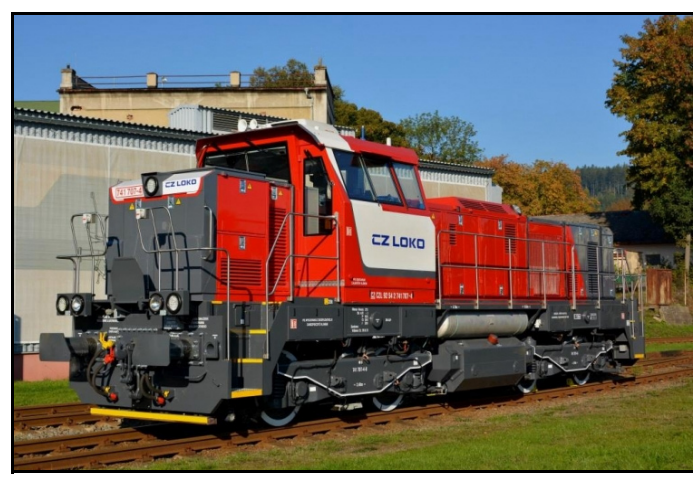

Rys. 3 - Widok pojazdu kolejowego typu 741.7 [6]

Fig. 3 - Picture of a 741.7 type vehicle [6]

Rama główna opisywanej lokomotywy jest osadzona za pomocą ośmiu metalowo gumowych poduszek na dwóch dwuosiowych wózkach, między którymi umieszczony jest zbiornik paliwa. Przenoszenie sił wzdłużnych z podwozia na ramę główną i odwrotnie zapewniają dwa rozciagane czopy. Agregat napędowy składa się z silnika spalinowego Caterpillar 3508C i alternatora trakcyjnego Siemens. Obie te maszyny są połączone $\mathrm{w}$ jeden zespół i za pośrednictwem wspólnej ramy pośredniej są elastycznie wsparte na ramie głównej lokomotywy.

Przeniesienie mocy z silnika spalinowego na zestawy kołowe jest elektryczne, typu prąd przemienny - prąd stały (AC/DC) i składa się z alternatora trakcyjnego, prostownika i czterech silników trakcyjnych. Silnik trakcyjny jest niezależny dla każdego zestawu kołowego $\mathrm{i}$ jest $\mathrm{w}$ nim umocowany za pomocą łożyskowania tocznego. W przedniej maszynowni znajduje się większość napędów pomocniczych, blok chłodnicy silnika spalinowego i blok pneumatyczny. W tylnej maszynowni znajduje się rozdzielnia elektryczna i blok hamulca elektrodynamicznego (EDB). Regulację mocy i całe sterowanie lokomotywy zapewnia elektroniczny system sterowania MSV elektronika z funkcją automatycznej regulacji prędkości (ARR). Lokomotywa jest wyposażona w trzy systemy hamulców na sprężone powietrze (samoczynny, bezpośredni, dodatkowy), ręczny hamulec mechaniczny (postojowy) i hamulec elektrodynamiczny (EDB). Hamulec na sprężone powietrze jest systemu DAKO-GP i pracuje w trybie towarowym i osobowym [6].
Another new technology are the shunting railway vehicles, types 741.7 and 742.7 , they are designed for medium-hard and hard shunting work and traffic on national and regional routes, as well as sidings with a gauge of $1435 \mathrm{~mm}$. Four-axle locomotives with a load of 18 tons per axle have an electric AC/DC power transmission. The locomotive is designed with a front and a tower-type driver cabin, positioned closer to the rear of the main frame. The locomotive axle system is B'o B'o and the maximum speed is 100 $\mathrm{km} / \mathrm{h}$. The vehicle is the result of comprehensive modernization of type 740,741, and 742 locomotives (or derivative types) [6].

The main frame of the described locomotive is fitted with eight metal and rubber pads on two two-axle bogies, with the fuel tank in between. Moving the longitudinal forces from the chassis to the main frame and vice versa is provided with two extended spigots. The drive unit consists of a Caterpillar 3508C combustion engine and Siemens traction alternator. Both of these machines are combined into a single unit and via a common intermediate frame are elastically supported on the main frame of the locomotive.

The transfer of power from the engine to the electric type wheelsets is done with mixed alternating and direct current (AC/DC), and consists of a traction alternator, battery charger and four traction motors. Each traction motor is independent for each wheelset and is secured with a rolling bearing. Most auxiliary drives are located in the front part of the train, the radiator engine block and the pneumatic block. At the rear there is the engine's electrical switchboard and the electrodynamic brake (EDB). Power regulation and control of the whole locomotive is done via an electronic control system, MSV electronics, with automatic speed control (ARR). The locomotive is equipped with three air brake systems (automatic, direct, axillary), manual mechanical brake (parking brake) and electrodynamic brake (EDB). Air brake system is a DAKO-GP and operates in freight and passenger modes [6].

\section{USING SPECIAL VEHICLES IN SHUNT- ING OPERATIONS}

\subsection{General characteristics}

An effective way to reduce the negative environmental impact of the combustion engine shunting locomotives currently in use may be their gradual replacement with special vehicles, including road-rail vehicles. Road-rail vehicles can move both on roads, as well as on railway tracks. Polish road-rail vehicles are built based on agricultural or commercial vehicles (light and heavy). Road vehicle reaches the features of a road-rail vehicle when equipped with a rail chassis, which allows it to ride on railway or tram tracks. 


\section{ZASTOSOWANIE POJAZDÓW SPECJAL- NYCH W PRACACH MANEWROWYCH}

\subsection{Charakterystyka ogólna}

Skutecznym sposobem zmniejszenia negatywnego oddziaływania na środowisko naturalne obecnie użytkowanych spalinowych lokomotyw manewrowych może być ich sukcesywne zastępowanie pojazdami specjalnymi, w tym szynowo-drogowymi. Pojazdy dwudrogowe mogą poruszać się zarówno po drogach kołowych, jak i po torach kolejowych. Polskie pojazdy szynowo-drogowe są budowane na bazie ciagników rolniczych lub samochodów użytkowych (lekkich i ciężkich). Pojazd drogowy osiaga cechy pojazdu dwudrogowego po wyposażeniu go w szynowy układ jezdny, który umożliwia mu jazdę po torach kolejowych lub tramwajowych.

Cechy konstrukcyjne tego typu pojazdów, a także ich mobilność, decydują o coraz szerszym ich zastosowaniu $\mathrm{w}$ europejskich zarządach kolejowych oraz $\mathrm{u}$ innych dysponentów torów kolejowych i tramwajowych. Datowany od lat 80 . XX w. rozwój polskich pojazdów dwudrogowych, zaowocował opracowaniem konstrukcji kilku rozwiązań szynowych układów jezdnych, które mogą mieć zastosowanie w seryjnie produkowanych ciagnikach rolniczych i pojazdach samochodowych o zróżnicowanej ładowności. W efekcie daje to szerokie możliwości stałej produkcji w kraju pojazdów szynowo-drogowych o różnym zastosowaniu i przeznaczeniu. $\mathrm{W}$ ostatnich latach przeważa zainteresowanie dostawą ciagników szynowo-drogowych do prowadzenia wszelkich prac manewrowych, a także różnych prac torowych.

\subsection{Ciągnik szynowo-kołowy}

Przykładem nowoczesnego ciagnika szynowodrogowego jest Arion model 620 firmy Claas, przystosowany do jazdy po drogach kołowych i szynach trakcji kolejowej, tramwajowej i metra. Pojazd pozwala między innymi na: jazdę po torach o szerokości $1435 \mathrm{~mm}$ i $1520 \mathrm{~mm}$ dzięki systemowi zmiennego rozstawu rolek szynowych; przetaczanie wagonów na bocznicach kolejowych, torach zakładowych, terminalach przeładunkowych; używanie pługa odśnieżnego i rozrzutnika piasku oraz holowanie przyczep drogowych (rys. 4) [7]. Pojazd ten jest produkowany przez firmę Claas i doposażony w układ szynowy w Instytucie Pojazdów Szynowych „Tabor” w Poznaniu. Na Międzynarodowych Targach Poznańskich, kolejny już raz, Instytut Pojazdów Szynowych „TABOR" został wyróżniony złotym medalem w kategorii „Produkt” za „Ciągnik szynowo-drogowy”.

Podstawowe dane techniczne ciagnika bazowego [7]:

- silnik 6 cyl. o mocy - $150 \mathrm{KM}$ nom., $158 \mathrm{KM}$ maks.,

-emisja spalin zgodna z obowiązującymi przepisami - Stage III b,
The design features of this type of vehicles, as well as their mobility, are the reasons for their increasingly common operation in the European railway management and in other disposers of railway and tram tracks. Dating back from the $80 \mathrm{~s}$ the development of the Polish road-rail vehicles, has resulted in the development of the construction of several rail chassis systems solutions, which can be used in mass-produced agricultural tractors and motor vehicles of varying capacity. The result is a wide possibility of permanent production of road-rail vehicles in the country for different applications and purposes. In recent years the interest in the possibilities of road-rail tractors for carrying out any shunting work, as well as a variety of track operations has been increasing.

\subsection{Road-rail tractor}

An example of a modern road-rail tractor is the Claas company model Arion 620, designed for road and rail track operations, including tram and subway rail. The vehicle allows, among other things: driving on a 1435 $\mathrm{mm}$ and $1520 \mathrm{~mm}$ gauge track thanks to variable rail roller spacing system; shunting operations on railway sidings, private tracks, reloading terminals, the use of a snow plow and sand spreader as well as road trailer towing (Fig. 4) [7]. This vehicle is manufactured by Claas and retrofitted with a rail system at the Rail Vehicles Institute "TABOR" in Poznan. The Rail Vehicles Institute "TABOR" was once again awarded the gold medal in the "product" category for "Road and rail tractor" at the Poznan International Fair.

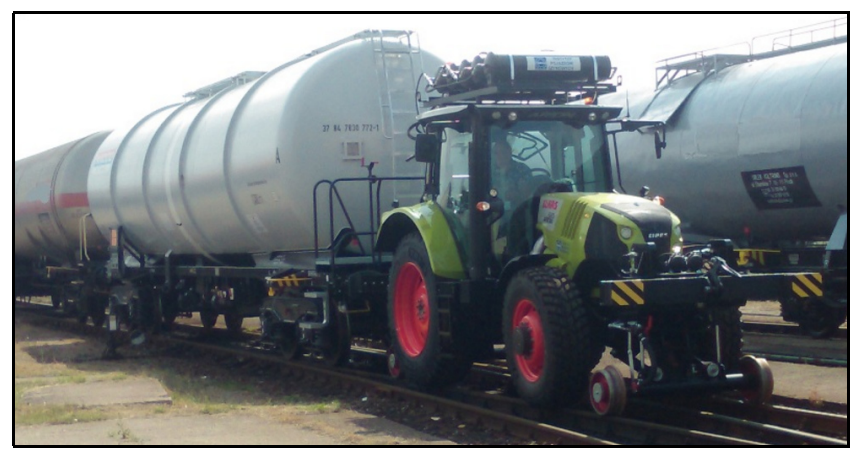

Rys. 4 - Ciagnik szynowo-kołowy przystosowany do prac manewrowych [7]

Fig. 4 - Road-rail tractor adjusted for shunting operations [7]

Main technical specifications of the base tractor [7]:

- 6 cylinder engine with $150 \mathrm{hp}$ nominal power, 158 hp max.,

- exhaust emissions in line with the current limits - Stage III b,

- manual air conditioning,

- cabin type - with shock absorbers,

- cold start system down to $-30^{\circ} \mathrm{C}$. 
-klimatyzacja - manualna,

-typ kabiny - amortyzowana,

-układ zimnego rozruchu do $-30{ }^{\circ} \mathrm{C}$.

Podstawowe dane ciagnika szynowo-drogowego [9]: $45 / 35 \mathrm{kN}$, maksymalna siła uciągu droga/tor -

- masa ciagnika szynowo-drogowego - $9700 \mathrm{~kg}$,

- maksymalna prędkość jazdy po drodze - 20 $\mathrm{km} / \mathrm{h}$,

- maksymalna prędkość jazdy po torze prostym, luzem $-20 \mathrm{~km} / \mathrm{h}$,

- maksymalna prędkość jazdy na łukach i rozjazdach z doczepionymi wagonami $5 \mathrm{~km} / \mathrm{h}$,

- dopuszczalna prędkość jazdy po torze prostym $\mathrm{z}$ wagonami, $\mathrm{z}$ hamulcem pneumatycznym -10 $\mathrm{km} / \mathrm{h}$.

W ciagniku Arion 620 pracuje 6-cylindrowa jednostka napędowa John Deere DPS o pojemności $6,8 \mathrm{dm}^{3}$. Ciagnik dysponuje mocą nominalną $150 \mathrm{KM} \mathrm{i} \mathrm{w}$ standardzie jest wyposażony $\mathrm{w}$ przekładnię Hexaschift 24/24.

Do głównych zalet ciagników szynowo-drogowych, $\mathrm{w}$ porównaniu $\mathrm{z}$ lokomotywami manewrowymi, zaliczyć można [5]:

- 3-krotnie niższą cenę zakupu ciagnika szynowokołowego w stosunku do ceny najtańszej lokomotywy

- 6-krotnie niższe koszty eksploatacji ciagnika

- 3-krotnie wyższe właściwości trakcyjne, możliwość prowadzenia pojazdów bez uprawnień kolejowych na bocznicach własnych, możliwość adaptacji użytkowanych pojazdów drogowych na pojazdy szynowo-drogowe.

\subsection{Samochód szynowo-drogowy}

Pojazdem o większej masie obsługiwanego składu jest samochód użytkowy Unimog (skrót od „Universal Motor Gerät”, niem. „Pojazd Uniwersalny"), przystosowany do ruchu kolejowego (rys. 5).

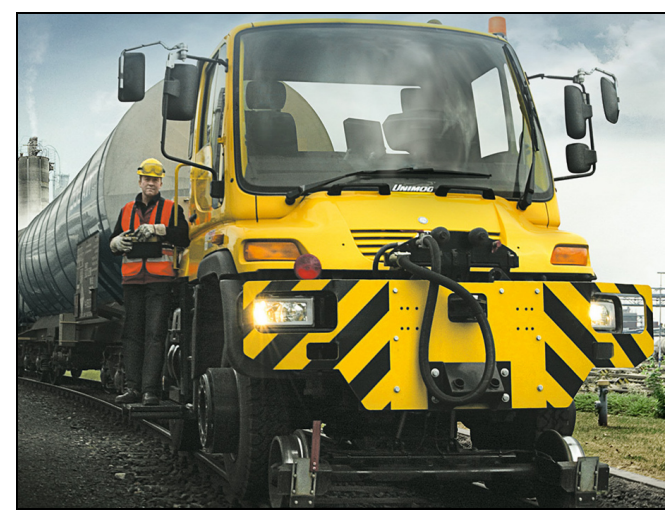

Rys. 5 - Samochód Mercedes-Benz Unimog U423 do zastosowań kolejowych [2]

Fig. 5 -Mercedes-Benz Unimog U423 utility vehicle for use on rail tracks [2]
Main technical specifications of the road-rail tractor [9]:

- maximum pulling power on $\mathrm{road} / \mathrm{rail}-45 / 35$ $\mathrm{kN}$,

- vehicle curb weight $-9700 \mathrm{~kg}$,

- max. on-road speed - $20 \mathrm{~km} / \mathrm{h}$,

- max. speed on a straight rail track $-20 \mathrm{~km} / \mathrm{h}$,

- max. speed on curved tracks and crossings when pulling carts $-5 \mathrm{~km} / \mathrm{h}$,

- max. allowed speed on straight track when pulling carts with air brakes $-10 \mathrm{~km} / \mathrm{h}$.

The Arion 620 tractor runs on a 6-cylinder power unit built by John Deere DPS with a displacement of 6.8 $\mathrm{dm}^{3}$. The tractor has $150 \mathrm{hp}$ nominal power and is normally equipped with a Hexaschift 24/24 transmission.

The main advantages of road-rail tractors, as compared to the shunting locomotives, can be listed as [5]:

- 3-times lower purchase cost for a road-rail tractor compared to the cheapest shunting locomotive,

- 6-times lower tractor operating costs,

- 3-times better traction properties, can be used by an operator without the need for a rail license while on own rail sidings, and the possibility of adapting currently used road vehicles for road-rail combined operations..

\subsection{Road-rail vehicles}

Unimog utility vehicle (,Universal Motor Gerät”, ger. ,universal utility vehicle”) adapted for use on rails can shunt train sets of higher combined weight (Fig. 5).

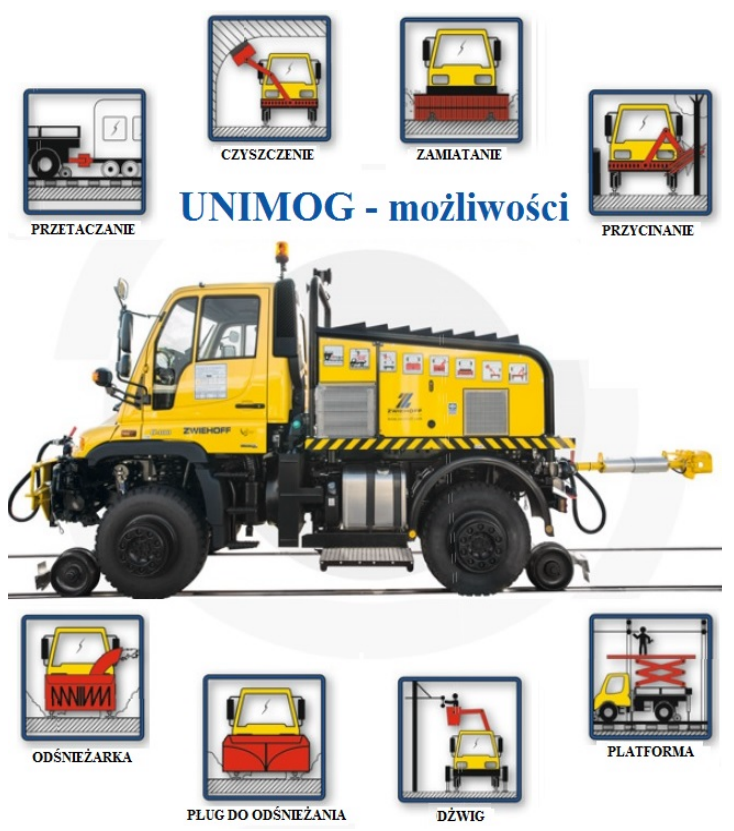

Rys. 6 - Zastosowania samochodu Mercedes-Benz Unimog U423 przy pracach torowo-drogowych [2]

Fig. 6 - Possible applications of Mercedes-Benz Unimog U423 for road-rail works [2] 
W samochodzie szynowo-drogowym Unimog U423 zastosowano najnowsze rozwiązania technologiczne dedykowane pojazdom wielozadaniowym. Nowy Unimog produkcji firmy Mercedes-Benz (koncern Daimler AG) jest następcą poprzedniej wersji tego pojazdu, spełniającego normę emisji spalin Euro V. W celu sprostania wymogom najnowszej normy Euro VI w opisywanym samochodzie wykorzystuje się zarówno nowoczesne rozwiązania silnikowe, jak i pozasilnikowe - wydajne układy oczyszczania spalin. Porównywalnie niższy koszt zakupu ww. pojazdu czyni go korzystną alternatywą wobec lokomotyw manewrowych.

Dotychczasowi użytkownicy określają zużycie paliwa Unimoga U423 na poziomie ok. $5-6 \mathrm{dm}^{3}$ oleju napędowego na każdą godzinę pracy [2, 9].

Unimog U423 dzięki dużej mocy silnika (170 kW) umożliwia prowadzenie prac manewrowych o łącznej maksymalnej masie obsługiwanego składu wynoszącej $1000 \mathrm{Mg}$. Zawdzięcza to również wykorzystaniu dużego współczynnika tarcia między oponami a szynami, co zapewnia właściwą trakcję. Dzięki kompaktowym wymiarom osi, pojazd ten nie potrzebuje osobnego napędu na szyny i może operować na różnych szerokościach torów. Hydrauliczny system opuszczania układu prowadzącego pozwala na bezpieczne przyłączenie się do torów na prostym odcin$\mathrm{ku}$ o długości zaledwie $5 \mathrm{~m}$. Przedmiotowy układ zapewnia stabilną i bezpieczną jazdę zarówno na prostych odcinkach linii kolejowych, jak również w ciasnych łukach o promieniu równym lub mniejszym niż $17 \mathrm{~m}$. Producent pojazdu umożliwia zamówienie fabrycznie zwiększonej przestrzeni podwoziowej, dzięki której (mimo rozstawu osi równego $3000 \mathrm{~mm}$ ) możliwe jest pełne podniesienie układu szynowego by wykonywać jazdę po drodze.

Unimog U423 w wersji do prac manewrowych jest wyposażony w system hamowania firmy KnorrBremse, który wykorzystuje sprężone powietrze do zatrzymywania pojazdu pod dużym obciążeniem. Posiada on napęd na cztery koła oraz skrzynię biegów z ośmioma biegami w przód i ośmioma wstecznymi, które pozwalają mu osiągać maksymalną prędkość jazdy $50 \mathrm{~km} / \mathrm{h}$ na torach (zarówno w jeździe do przodu, jak i wstecz). Zamontowany w nim system EasyDrive pozwala na łatwą zmianę w czasie jazdy między napędem hydrostatycznym a przekładnią mechaniczną. Opisywany Unimog jest ponadto wyposażony w system zdalnej kontroli pracy [2, 9].

\subsection{Pojazd szynowo-drogowy typu Locotractor}

Kolejną grupą pojazdów o większej masie są Locotractory (rys. 7). Sa to pojazdy szynowo-drogowe (dwufunkcyjne), które mogą poruszać się po torach oraz po drogach przeznaczonych dla ruchu kołowego. Możliwość jazdy w terenie realizowana jest przez koła drogowe. W trybie jazdy po torach pojazd wykorzystuje szynowy układ jezdny. Hydraulicznie opuszczane stalowe rolki prowadzące zapewniają pewne
The road-rail Unimog U423 vehicle is fitted with the latest technology solutions dedicated for multipurpose vehicles. The new Unimog of MercedesBenz (Daimler AG) is the successor to the previous version of this vehicle, and meets the Euro $\mathrm{V}$ emissions standard. In order to meet the requirements of the latest Euro VI standard the vehicle uses modern engine and aftertreatment solutions - efficient systems of exhaust gas aftertreatment. Comparatively lower purchase cost of this vehicle, makes it a favorable alternative to shunting locomotives.

Current operators of this vehicle determine the fuel consumption of Unimog U423 at approx. 5-6 $\mathrm{dm}^{3}$ of diesel fuel for every hour of work [2,9].

Thanks to the high engine power $(170 \mathrm{~kW})$ the Unimog U423 allows carrying out shunting with a total maximum mass of a pulled set of $1000 \mathrm{Mg}$. This is due to the use of high friction coefficient between the tires and rails which provides adequate traction. With its compact axle dimensions, the vehicle does not need a separate drive for moving on rails and can operate on different track gauges. Hydraulic lowering of the track guiding system allows for safe connection to the tracks on a straight section with a length of only $5 \mathrm{~m}$. The present system provides a stable and safe driving both on straight stretches of railway lines as well as tight curves with a radius equal to or less than $17 \mathrm{~m}$. The manufacturer offers ordering the vehicle with increased ground clearance, thanks to which (despite the wheel separation equal to 3000 $\mathrm{mm}$ ) the rail system can be fully lifted to allow driving on the road.

Unimog U423 in the shunting version is equipped with a Knorr-Bremse braking system, which uses compressed air to stop the vehicle under heavy load. It has a four-wheel drive and a transmission with eight forward gears and eight in reverse, that allow it to reach a maximum speed of $50 \mathrm{~km} / \mathrm{h}$ on the tracks (both driving forwards and backwards). The EasyDrive system it is equipped with allows users to change while driving between hydrostatic and mechanical transmission. The mentioned Unimog is further provided with a system for remote control of its operation $[2,9]$.

\subsection{Locotractor road-rail vehicle type}

Another group of vehicles with higher pulling weight are Locotractors (Fig. 7). These are road-rail vehicles (dual function), which can move on rails and roads intended for vehicular traffic. Road driving is done using the road wheels. In rail driving mode the vehicle uses rail track chassis. Hydraulically lowered steel rollers provide an attachment of the vehicle to the track, while driving and braking is done using the road wheels.

The Locotractor family is divided into 9 models (Fig. 7), from light rail tractor with a drawbar pull of $600 \mathrm{t}$, 
„zazbrojenie” pojazdu na torze, przy czym napęd i hamowanie realizowane jest przez koła drogowe.

Rodzina Locotractorów dzieli się na 9 modeli (rys. 7), począwszy od lekkich ciagników szynowych o uciagu 600 t kończąc na ciężkich ciągnikach szynowych o uciągu 4600 t. Możliwość zastapienia tradycyjnych lokomotyw manewrowych przez połowę lżejsze pojazdy szynowo-drogowe w tym rozwiązaniu uzyskano dzięki zastapieniu stalowych kół napędowych kołami gumowymi. Dzięki zwiększonemu współczynnikowi tarcia pomiędzy szyną a kołem, pomimo mniejszej mocy znamionowej w stosunku do lokomotyw, siła pociągowa przy ruszaniu $\mathrm{z}$ miejsca jest na podobnym poziomie.

Główną zaletą Locotractorów jest możliwość poruszania się w sposób całkowicie niezależny po torach, jak i po drodze. Pod względem sprawności silnika są bardziej wydajne, dają większą siłę pociągową przy ruszaniu z miejsca w stosunku do maksymalnej mocy silnika. Zapewniaja komfortowe warunki pracy operatorowi dzięki klimatyzacji oraz dużemu polu widzenia. Mają niewielkie wymagania $\mathrm{w}$ przypadku wykorzystania infrastruktury obsługowej, np. miejsce postoju, naprawy. $Z$ zastosowaniem zdalnego sterowania manewry mogą być prowadzone przez jedną osobę, podczas gdy w przypadku lokomotyw drużynę manewrową stanowią 2 lub 3 osoby. Dodatkowo koszty eksploatacji są zredukowane o co najmniej $50 \%$. Pojazdy te pozwalają również na wykonywanie prac w zamkniętych halach, magazynach [8].

\section{ZAKOŃCZENIE}

Dzięki pojazdom szynowo-drogowym możliwa jest optymalizacja kosztowa i operacyjna czynności manewrowych w określonych kategoriach. Mniejsze pojazdy elektryczne o uciagach od 250 do $500 \mathrm{t}$ znajdują zastosowanie zwłaszcza w manewrach wewnątrz hal obsługowych ze względu na brak emisji to heavy rail tractors pulling up to $4,600 \mathrm{t}$. The possibility of replacing the traditional shunting locomotives by half lighter road-rail vehicles, was achieved in this solution by replacing the steel drive wheels with rubber wheels. With the increased friction coefficient between the rail and the wheel, despite a lower power rating compared to locomotives, the starting tractive force is on a similar level.

The main advantage of the Locotractor is the ability to move in a completely independent manner on the track and on the road. They are more efficient in terms of engine efficiency, provide more pulling power when starting relative to the maximum engine power. They provide comfortable working conditions for the operator thanks to the air conditioning and a large field of view. They have low infrastructure maintenance requirements, for example: parking place, repair. With the help of the remote control system, vehicle maneuvers can be carried out by one person, while in the case of locomotives shunting teams usually consist of 2 or 3 people. In addition, the operating costs are reduced by at least $50 \%$. These vehicles can also carry out work in closed halls and warehouses [8].

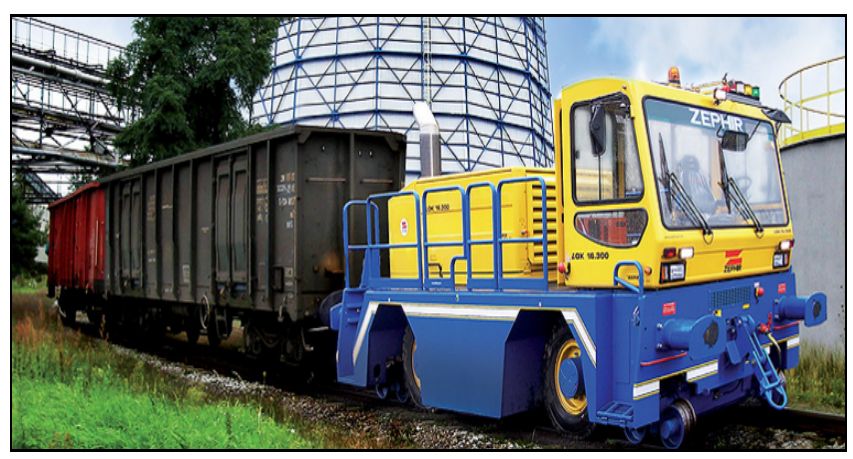

Rys. 7 - Pojazd szynowo-drogowy typu Locotractor [8]

Fig. 7 -Locotractor type road-rail vehicle [8]

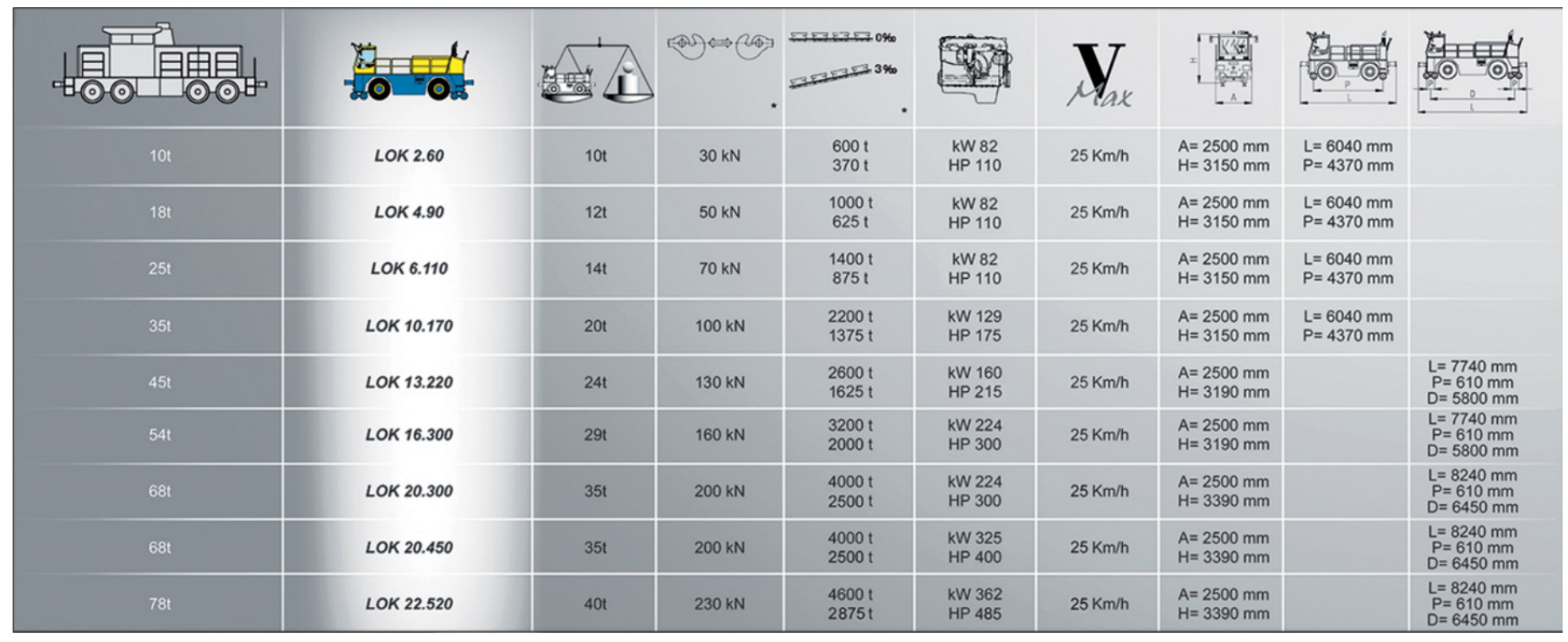

Rys. 8 - Modele pojazdów szynowo-drogowych typu Locotractor [8]

Fig. 8 -Locotractor type road-rail vehicle models [8] 


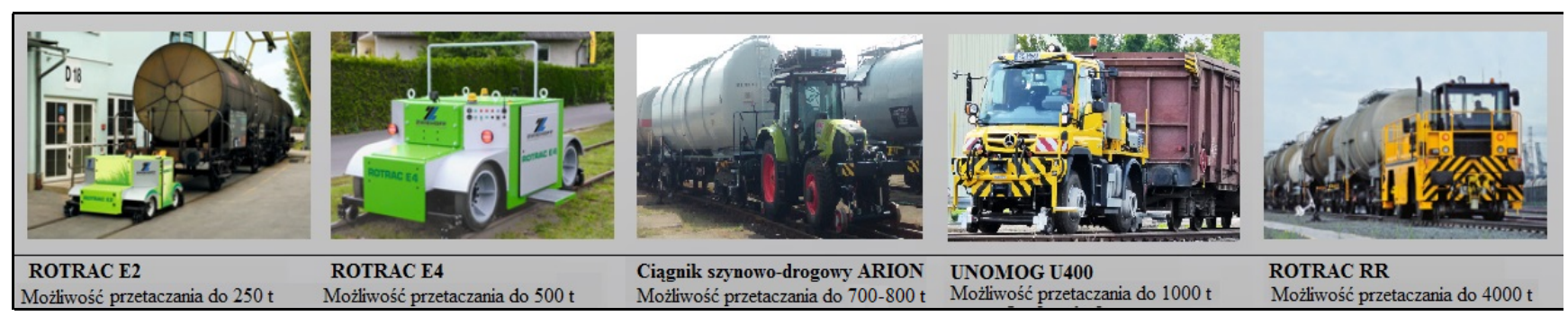

Rys. 9 - Zestawienie możliwości przetaczania przez pojazdy szynowo-drogowe

Fig. 9 - Summary of road-rail vehicles shunting capabilities

spalin oraz cichą pracę. Zestawienie możliwości przetaczania przez różne pojazdy szynowo-drogowe przedstawia rysunek 9. Pojazdy na bazie samochodu ciężarowego Mercedes-Benz Unimog U423 przeznaczone są do cięższej pracy w warunkach zewnętrznych o możliwościach przetaczania do 1000 t, zapewniając nadwyżkę mocy na przetaczanie ponad $1000 \mathrm{t}$ po suchym, prostym i płaskim torze.

W porównaniu do klasycznych lokomotyw manewrowych typu SM42 wykonując te same prace za pomocą pojazdu Unimog oszczędności szacuje się na poziomie $50 \% \mathrm{w}$ odniesieniu do całkowitego cyklu życia pojazdu. Redukcja emisji hałasu i spełnienie aktualnych norm emisji spalin gwarantuje zachowanie bezpiecznego otoczenia pracownikom bocznic i zapleczy. Aktualnie pojazdy szynowo-drogowe moga wykonywać pracę tam, gdzie użycie tradycyjnych lokomotyw jest ekonomicznie nieuzasadnione lub po prostu niemożliwe. W przyszłości zaczną odbierać coraz więcej pracy lokomotywom manewrowym, przy redukcji kosztów zakupu, użytkowania i okresowej obsługi.

Dodatkowym impulsem do wymiany lokomotyw na pojazdy szynowo-drogowe i redukcji kosztów operacji manewrowych, jest fakt uzyskania w 2015 r. homologacji UTK przez pojazd Unimog U423 Euro 6. Według analiz oszczędności $\mathrm{z}$ eksploatacji takich pojazdów powinny być rozpatrywane $\mathrm{w}$ ujęciu 3-5 lat. W porównaniu do lokomotywy manewrowej daje bowiem oszczędności nie tylko paliwa i innych materiałów eksploatacyjnych, lecz także w wydatkach na konserwację, serwisowanie oraz częściowe i pełne badania techniczne. Przeglądy pojazdu Unimog wynikające $\mathrm{z}$ systemu utrzymania są kilkanaście razy tańsze, niż koszty przeglądów lokomotywy. Rynek w Polsce na tego typu pojazdy ciagle się rozwija, co znajduje odzwierciedlenie w rosnącej liczbie dostaw oraz zwiększającej się liczbie zapytań ofertowych. Patrząc na środowisko naturalne użytkowanie pojazdów szynowo-drogowych istotne przyczynia się do jego ochrony, gdyż jest to sprzęt spełniający najnowsze standardy emisji spalin.

\section{CONCLUSIONS}

It is possible to optimize cost and operation of shunting activities in certain categories by using road-rail vehicles. Smaller electric vehicles with pulling power from 250 to $500 \mathrm{t}$ are used especially in the maneuvering inside maintenance halls, due to their lack of emissions and quiet operation. Figure 9 provides a summary of shunting possibilities by various road-rail vehicles. Vehicles based on Mercedes-Benz Unimog U423 vehicle are designed for work in the open areas pulling heavier loads of up to $1,000 \mathrm{t}$, while providing excess pulling capacity of more than 1,000 tons on dry, straight and flat track.

In comparison to the classic type of shunting locomotives SM42 performing the same work, an Unimog vehicle provides an estimated savings of $50 \%$ relative to the total vehicle life cycle. Reduction of noise emissions and adherence to the current emission standards guarantees a safe working environment to employees on sidings and in support facilities. Currently, road-rail vehicles can perform the work where the use of conventional locomotives is economically unreasonable or simply impossible. In the future, they will likely take over more and more of the locomotives shunting work, while reducing the costs of purchase, operation and periodic vehicle maintenance.

An additional reason to exchange shunting locomotives for road-rail vehicles and reduce shunting operation costs is that in 2015 the Unimog U423 vehicle passed the UTK Euro 6 type approval tests. According to the analysis, the savings from the use of such vehicles should be considered in terms of 3-5 year time span. Because compared to shunting locomotives this vehicle can provide savings not only in the costs of fuel and other supplies, but also in maintenance, servicing as well as partial and full technical fitness tests. Interim reviews of the Unimog vehicle are several times cheaper than the costs of locomotive maintenance resulting from the different maintenance system. The polish market for such vehicles is still developing, which is reflected in the increasing number of supplied vehicles and the increasing number of purchase inquiries. From the environmental perspective the use of road-rail vehicles can provide a substantial contribution to the protection of the environment, because the equipment and vehicle meet the latest emissions standards. 


\section{BIBLIOGRAPHY LITERATURA}

[1] Bolewski S., Kowalczyk E.: Lokomotywy spalinowe serii SM42 i SP42. Wydawnictwa Komunikacji i Łączności, Warszawa 1986.

[2] Materialy koncernu Daimler: www.daimler.com, www.mercedes-benz.com (dostęp z dnia 13.03.2016).

[3] Materiaty Polskich Kolei Państwowych.

[4] Materiaty firmy PKP Cargo.

[5] Medwid M.: Hybrydowe pojazdy kolejowo-drogowe zaprojektowane i wytwarzane w Polsce. Technika Transportu Szynowego, 7-8/2005, s. 45? 53.

[6] www.czloko.cz (dostęp z dnia 13.03.2016).

[7] www.tabor.com.pl (dostęp z dnia 24.03.2016).

[8] www.wichary.eu (dostęp z dnia 24.03.2016).

[9] www.zwiehoff.com (dostep z dnia 24.03.2016). 